\title{
Do Not Distribute, Transfer, Loan, or Sell Product
}

National Cancer Institute

\section{Source}

National Cancer Institute. Do Not Distribute, Transfer, Loan, or Sell Product. NCI

Thesaurus. Code C128518.

The healthcare provider or setting must not distribute, transfer, loan, or sell the product. 